\title{
Ritual and remembrance at a prehistoric ceremonial complex in central Scotland: excavations at Forteviot, Perth and Kinross
}

Gordon Noble ${ }^{1} \&$ Kenneth Brophy ${ }^{2}$

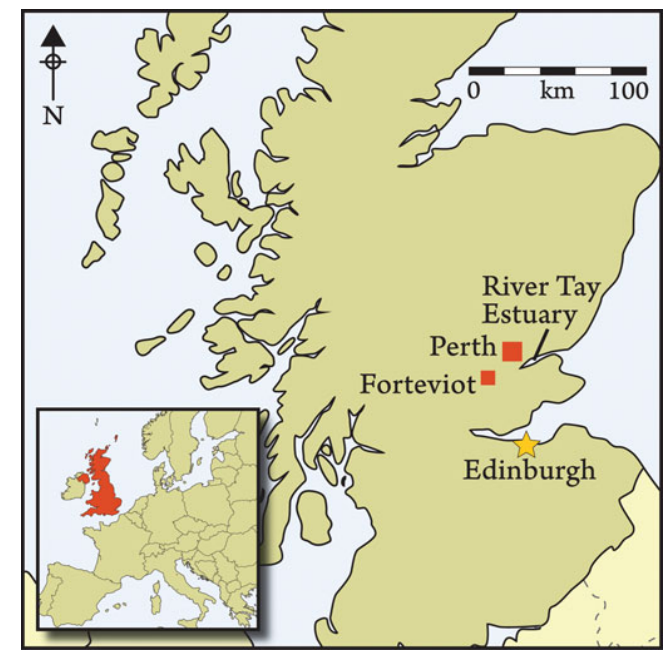

Aerial photography and excavations have brought to notice a major prehistoric ceremonial complex in central Scotland comparable to Stonehenge, although largely built in earth and timber. Beginning, like Stonehenge, as a cremation cemetery, it launched its monumentality by means of an immense circle of tree trunks, and developed it with smaller circles of posts and an earth bank (henge). A change of political mood in the Early Bronze Age is marked by one of Scotland's best preserved dagger-burials in a stone cist with an engraved lid. The perishable (or reusable) materials meant that this great centre lay for millennia under ploughed fields, until it was adopted, by design or by chance, as a centre of the Pictish kings.

Keywords: Scotland, Strathearn, Neolithic, Bronze Age, third millennium BC, cremation, palisaded enclosure, timber circles, henge, cist burial, dagger burial, Pictish palace

\section{Introduction}

The Perthshire village of Forteviot in central Scotland has been cited since the seventeenth century as the location of a ninth-eleventh century AD royal palace and a fine collection of Pictish carved stones and crosses (Alcock \& Alcock 1992; Aitchison 2006). However, it took

1 Department of Archaeology, University of Aberdeen, St Mary's Building, Elphinstone Road, Aberdeen AB24 3UF, UK (Author for correspondence, email: g.noble@abdn.ac.uk)

2 School of Humanities, University of Glasgow, The Gregory Building, Lilybank Gardens, Glasgow G12 8QQ, UK (Email: kenny.brophy@glasgow.ac.uk) 


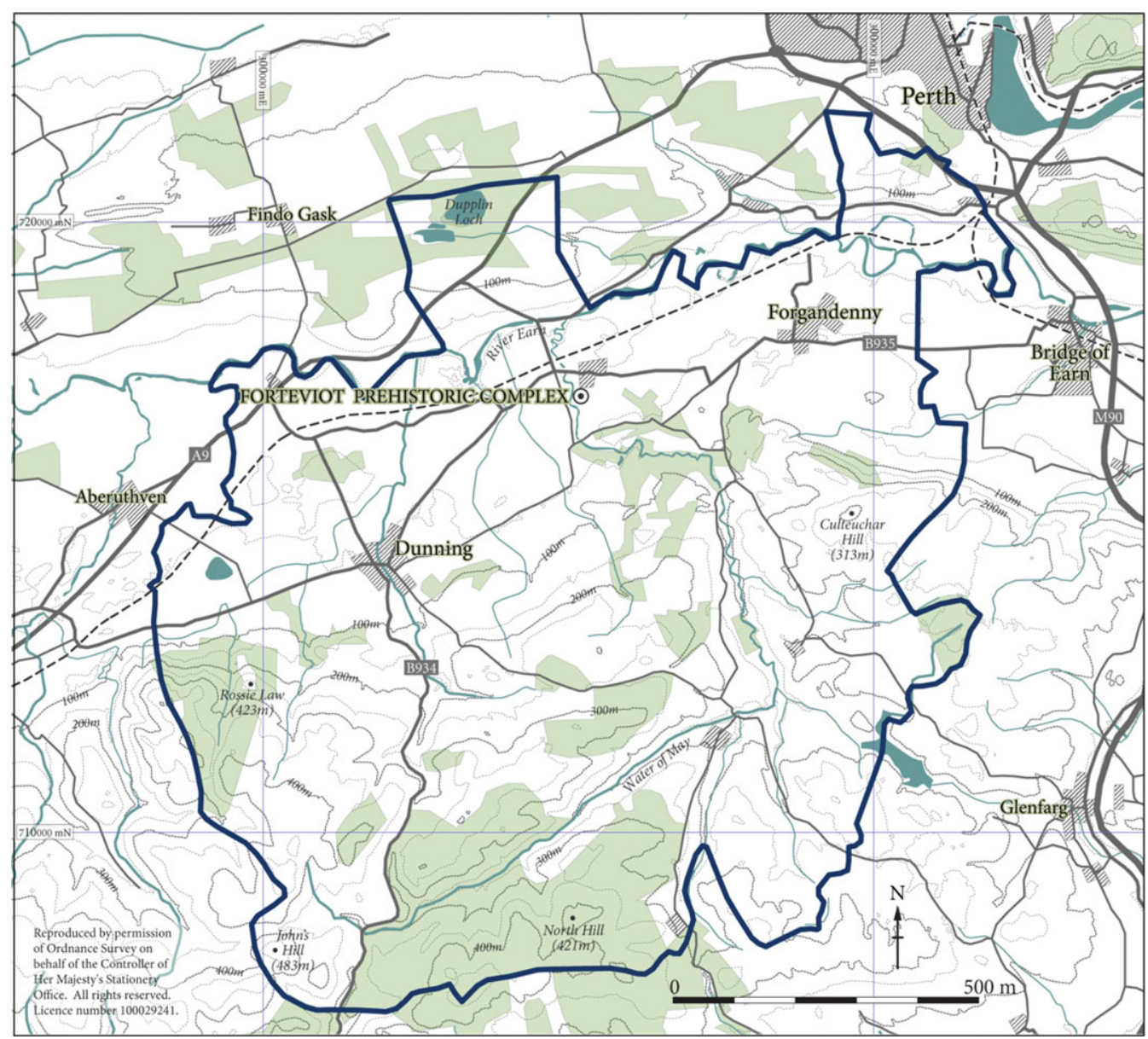

Figure 1. Strathearn in central Scotland showing the area being researched by the Strathearn Environs and Royal Forteviot project. (Reproduced by permission of Ordnance Survey on behalf of the Controller of Her Majesty's Stationery Office. All rights reserved. Licence number 100029241.)

aerial archaeology to reveal the deeper, prehistoric significance of this place to the extent that, although 3000 years apart, the early medieval and Late Neolithic can now be regarded as representing two periods when the area flourished as a centre of power, perhaps both sacred and secular. Forteviot lies on a prominent routeway across the Scottish peninsula, connecting the Firth of Tay with the Western Isles. Its prehistoric role may thus be evaluated in the light of the later role of the valley in confronting the historic Scots and Picts (Figure 1). Its prehistoric character has now been defined in more detail by the Strathearn Environs and Royal Forteviot (SERF) project (Driscoll et al. 2010), which has revealed it as one of the most intensively developed prehistoric ceremonial landscapes in Britain. Discoveries include a later Neolithic cremation cemetery, a series of earth and timber monuments and a spectacular Bronze Age burial (Figure 2). 


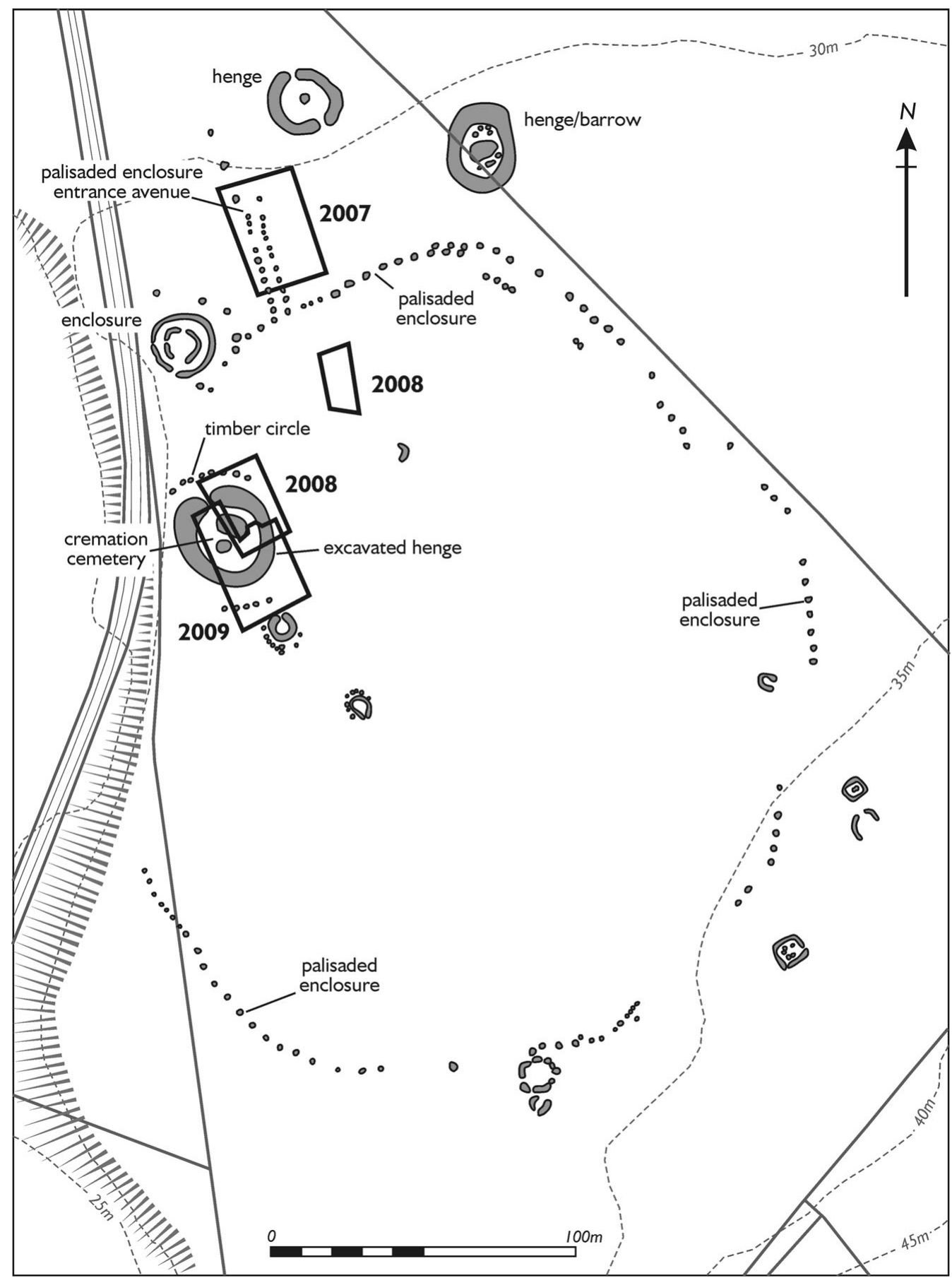

Figure 2. The prehistoric complex at Forteviot as so far known, with excavation areas. 


\section{Discovery and investigation}

Monuments were first identified from the air as cropmarks just to the south of the village of Forteviot in 1970 (St Joseph 1976) (Figure 3). The largest was a massive palisaded enclosure of later Neolithic type (2800-2500 cal BC) some $265 \mathrm{~m}$ across and enclosing an area approximately 6ha in size (Gibson 2002: 18; Noble \& Brophy 2011) (Figure 2). Cropmark evidence also indicated an earth henge monument within the palisaded enclosure, surrounded by a timber circle some $45 \mathrm{~m}$ in diameter (Figure 2, centre left). Outside the palisaded enclosure lay another possible henge with two entrances and a circular ditched feature that may be a barrow or a reworked henge, and another enclosure containing a possible post-built roundhouse (Figure 2, top). All of these monuments, with the exception of the later prehistoric settlement enclosure, are likely to date to the third millennium cal BC. Reconnaissance since the 1970s has confirmed the scale and form of this complex, and also revealed the cropmarks of an early medieval cemetery in the vicinity (Alcock \& Alcock 1992; Driscoll et al. 2010). As part of the SERF project, we carried out excavations in 2007-2009 on two elements of the Forteviot prehistoric cropmark complex: the palisaded enclosure entrance avenue and the timber circle or henge within this enclosure (for interim accounts see Noble \& Brophy 2008, 2009; Brophy \& Noble 2010).

\section{Results}

\section{Cremation cemetery}

Amongst the earliest activity was a series of cremation deposits, part of an extensive and unusual cremation cemetery dating to the start of the third millennium cal BC: 3090-2638 cal BC (Figure 4) (Tables $1 \& 2$ ). These were found in the western half of the henge monument within the palisaded enclosure, although they pre-dated the henge by at least three centuries. Nine discrete cremation deposits were excavated in 2009 and extensive spreads of more dispersed cremated material was found within silty spreads across the henge interior. The particular disposition of these burials suggests they had originally been placed within flat-based wooden vessels. The cremated material includes the remains of adults and young children as well as small amounts of animal bone; some deposits may have represented at least two individuals (Arabaolaza 2010).

The area in which the burials were found has only been sampled to date but based on this sample it is likely that many more burials are present. The excavated cremations tended to be associated with cut features, from shallow scoops with single deposits to a large round pit some $1.26 \mathrm{~m}$ in diameter and $0.5 \mathrm{~m}$ deep that contained a number of burials, two in small re-cuts of this feature. One of the cut features, associated with a single cremation deposit, was found to contain a fragment of a sandstone slab that may be a snapped standing stone, implying that one or more of the burials may have been marked by an upright stone. The cremations were generally unaccompanied, but one included a small fragment of a bone pin, and another the sherds of an undecorated pot. A fine leaf-shaped arrowhead was also found within one of the silt spreads associated with cremated bone. These cremations and silt deposits extended over an area measuring $15 \times 9 \mathrm{~m}$ and might originally have been more extensive. Perhaps the remains of some form of low barrow existed here; however the full 


\section{Gordon Noble \& Kenneth Brophy}

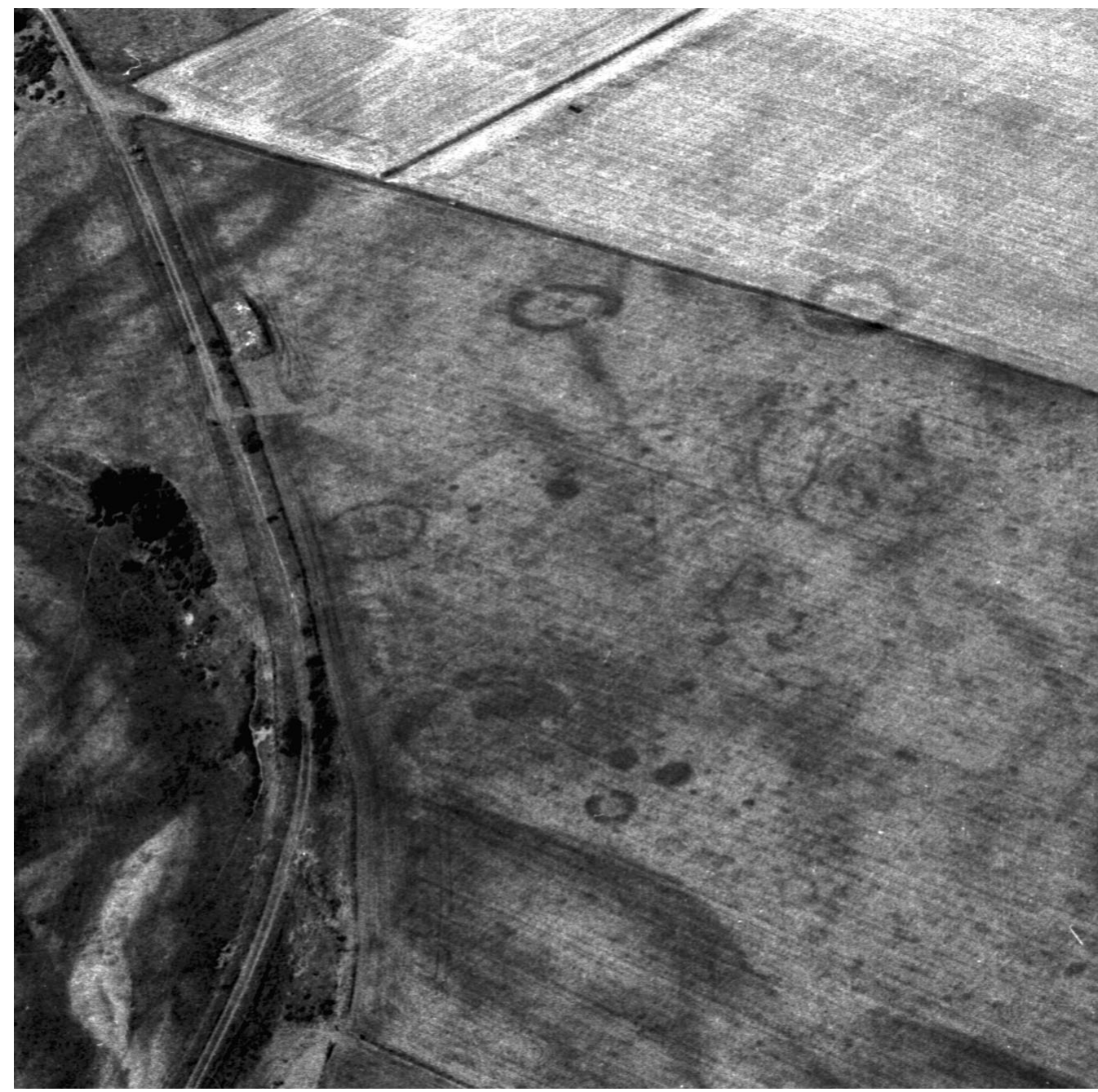

Figure 3. Aerial photograph of the henge and timber circle prior to excavation (C)RCAHMS, John Dewar Collection. Licensor www.rcahms.gov.uk).

extent of the cemetery and any associated mound is uncertain due to the radical reworking of this location (see Figure 6 below).

\section{Great palisaded enclosure}

The cremation cemetery at Forteviot was followed closely by the construction of a palisaded enclosure that encircles the cemetery and a large area around it. Similar palisaded enclosures are known in Britain - four in Scotland (Noble \& Brophy 2011) and one in Walton, Wales (Gibson 2002) — but our excavations in 2007 represent the first time that the entrance avenue of a palisaded enclosure of this type has been excavated (Figure 2, top; Figure 5). Sixteen of the 18 entrance avenue posts were uncovered; the avenue itself was approximately $35 \mathrm{~m}$ in length but only $4-5 \mathrm{~m}$ wide. The largest postholes were over $1 \mathrm{~m}$ deep and typically 


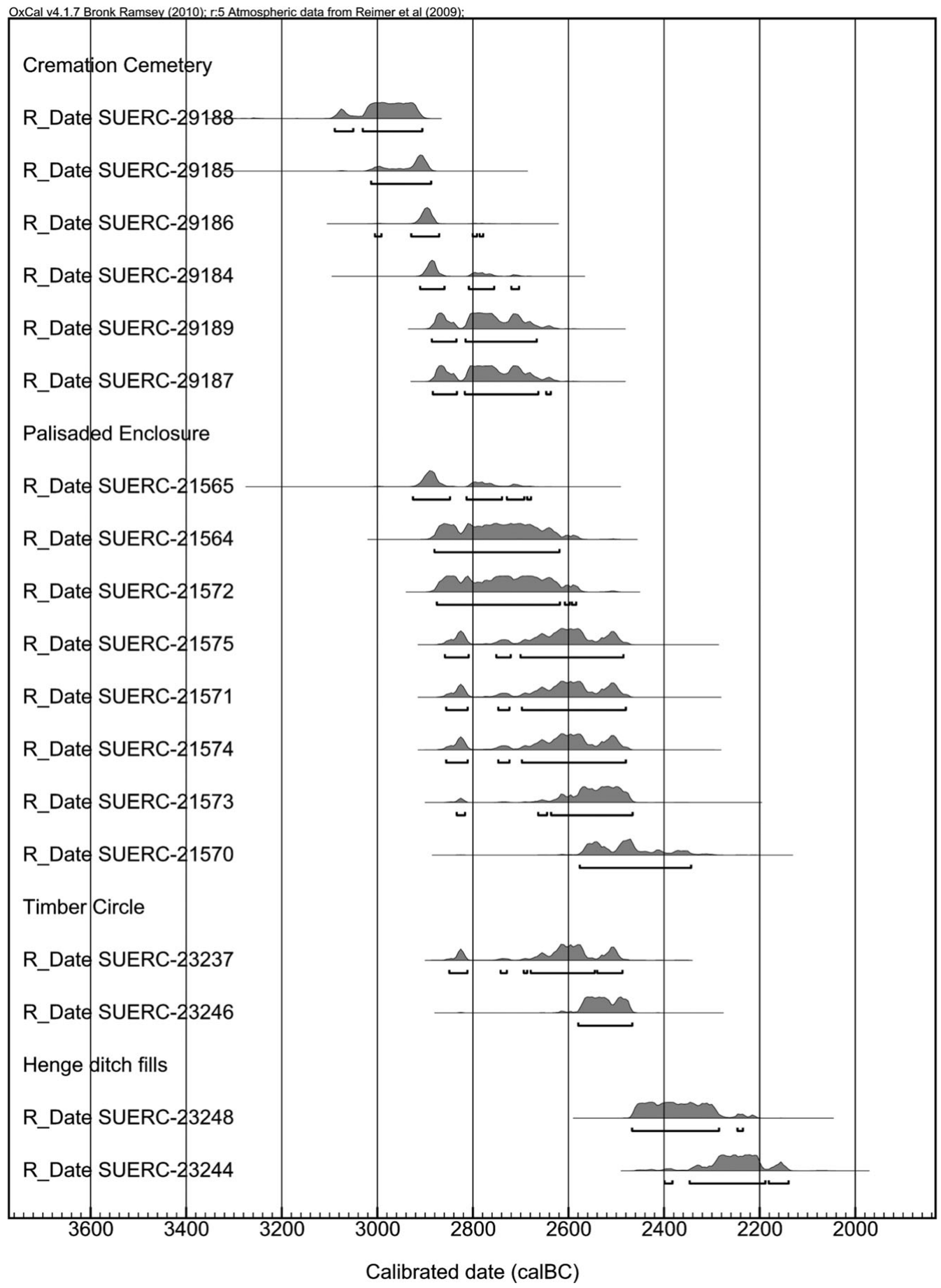

Figure 4. Radiocarbon dates for the Forteviot ceremonial complex (OxCal). 


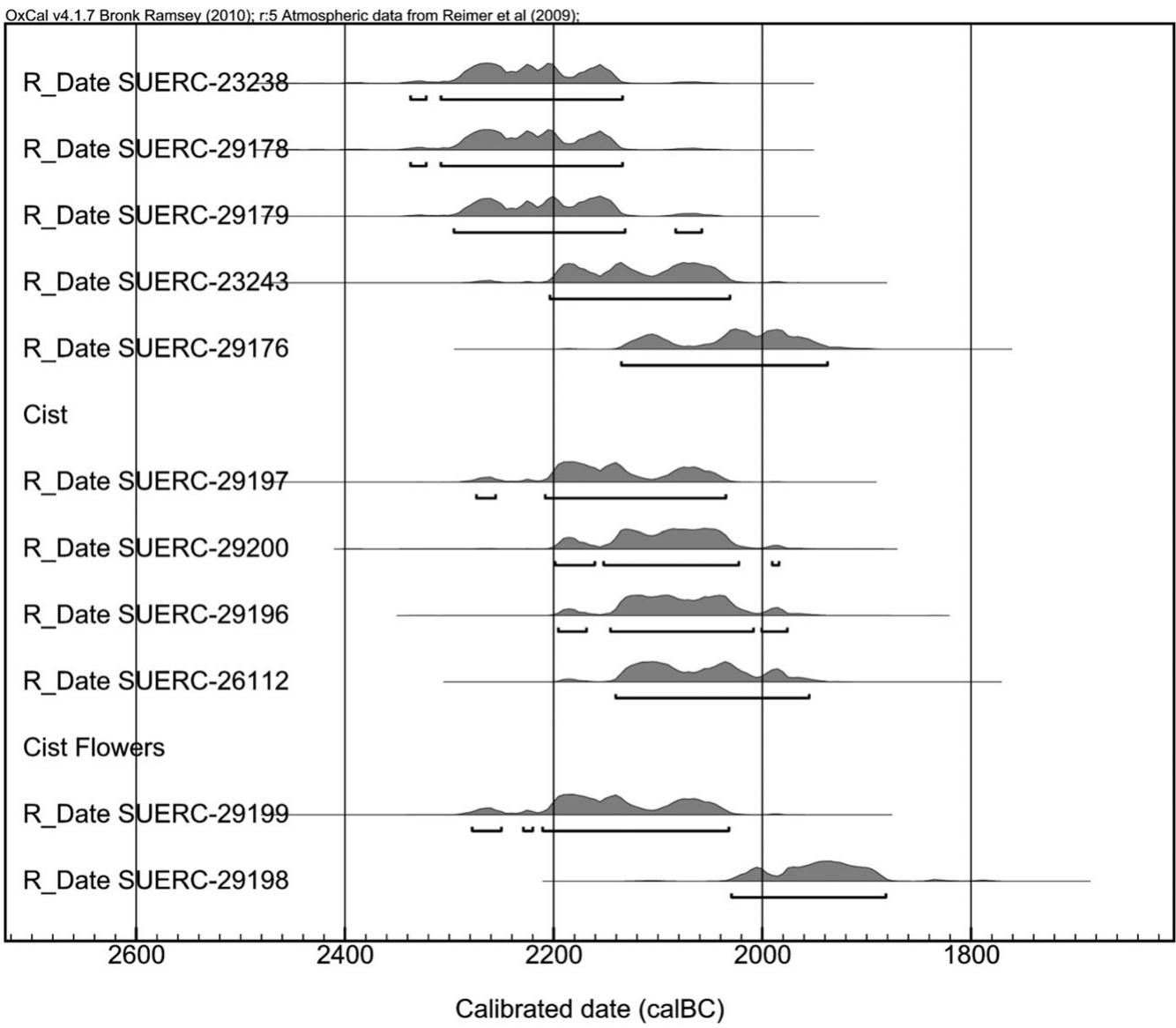

Figure 4. Continued.

up to $2 \mathrm{~m}$ across, with ramps present to help lower large timbers into place. Post-pipes ranged from $0.6-0.9 \mathrm{~m}$ in width where identified, suggesting postholes once held very large posts or more likely whole tree trunks. Estimates of the post heights based on posthole depth suggest posts as high as $6 \mathrm{~m}$ could have been supported by the ramped postholes and if this is the case these timbers will have weighed at least one or two tons (Gibson 2002: 14-15; Noble \& Brophy 2011).

Little artefactual material was found at the avenue, aside from fragments of cremated bone in the upper fills of a number of the avenue posts. A series of AMS radiocarbon dates obtained for the avenue show that it was in use in the centuries 2926-2467 cal BC (Figure 4) (Tables $1 \& 2$ ), in line with other palisaded enclosures of this form (Gibson 2002: 5) (every effort was made to select material for dating that was not heartwood and therefore likely to have been relatively short-lived).

It was concluded that the entrance avenue and the boundary of the palisade was marked out by unevenly-spaced large oak tree trunks, arranged in an irregular circle. The overall boundary, in the order of 600-700m in length, suggests around 200 timbers were required 
Table 1. Radiocarbon dates obtained so far for the Forteviot monument complex (calibrated using Oxcal 4.1).

\begin{tabular}{|c|c|c|c|c|c|}
\hline Lab no. & Material & Context/sample & $\begin{array}{l}\text { Radiocarbon } \\
\text { age (BP) }\end{array}$ & $\begin{array}{c}\delta^{13} \mathrm{C} \\
\text { relative } \\
\text { to } \mathrm{VPDB}\end{array}$ & $\begin{array}{l}\text { Calibrated date } \\
\text { range }(95 \% \\
\text { confidence })\end{array}$ \\
\hline SUERC-29184 & Charcoal: Alnus & 628/1050 Cremation & $4240 \pm 30$ & -26.7 & 2911-2704 cal BC \\
\hline SUERC-29185 & Charcoal: Alnus & 641/1070 Cremation & $4315 \pm 30$ & -26.4 & 3014-2888 cal BC \\
\hline SUERC-29186 & $\begin{array}{l}\text { Cremated bone: human lower } \\
\text { long bone shaft fragment }\end{array}$ & 617b/1041 Cremation & $4275 \pm 30$ & -22.6 & $3006-2779 \mathrm{cal} \mathrm{BC}$ \\
\hline SUERC-29187 & $\begin{array}{l}\text { Cremated bone: human lower } \\
\text { long bone shaft fragment }\end{array}$ & 628b/1050 Cremation & $4175 \pm 30$ & -22.0 & $2885-2638 \mathrm{cal} \mathrm{BC}$ \\
\hline SUERC-29188 & $\begin{array}{l}\text { Cremated bone: human lower } \\
\text { long bone shaft fragment }\end{array}$ & 641b/1070 Cremation & $4370 \pm 70$ & -21.2 & $3090-2907 \mathrm{cal} \mathrm{BC}$ \\
\hline SUERC-29199 & Cremated bone: human femur & 530b/1049 Cremation & $4180 \pm 30$ & -25.7 & $2887-2667 \mathrm{cal} \mathrm{BC}$ \\
\hline SUERC-21564 & Charcoal: Quercus & 159/066 Pal. enclosure & $4155 \pm 40$ & -25.2 & $2881-2620 \mathrm{cal} \mathrm{BC}$ \\
\hline SUERC-21565 & Charcoal: Quercus & 150/058 Pal. enclosure & $4250 \pm 40$ & -25.9 & 2926-2679 cal BC \\
\hline SUERC-21570 & Charcoal: Quercus & 121/SF061 Pal. enclosure & $3965 \pm 40$ & -25.7 & $2577-2344 \mathrm{cal} \mathrm{BC}$ \\
\hline SUERC-21571 & Charcoal: Quercus & 118/SF051 Pal. enclosure & $4065 \pm 40$ & -26.2 & $2857-2481 \mathrm{cal} \mathrm{BC}$ \\
\hline SUERC-21572 & Charcoal: Quercus & 103/050 Pal. enclosure & $4140 \pm 40$ & -24.2 & $2876-2585 \mathrm{cal} \mathrm{BC}$ \\
\hline SUERC-21573 & Charcoal: Quercus & 032/053 Pal. enclosure & $4025 \pm 40$ & -24.7 & $2835-2467 \mathrm{cal} \mathrm{BC}$ \\
\hline SUERC-21574 & Charcoal: Quercus & 044/043 Pal. enclosure & $4065 \pm 40$ & -25.8 & $2857-2481 \mathrm{cal} \mathrm{BC}$ \\
\hline SUERC-21575 & Charcoal: Quercus & 112/SF020 Pal. enclosure & $4070 \pm 40$ & -24.9 & 2859-2486 cal BC \\
\hline SUERC-23237 & Charcoal: Quercus & 334/313 Timber circle & $4065 \pm 30$ & -27.7 & $2850-2488 \mathrm{cal} \mathrm{BC}$ \\
\hline SUERC-23246 & Charcoal: Quercus & 333/331 Timber circle & $4005 \pm 30$ & -27.5 & $2580-2467 \mathrm{cal} \mathrm{BC}$ \\
\hline SUERC-23238 & Charcoal: Corylus & $311 / 316$ Henge ditch upper fill & $3790 \pm 30$ & -25.1 & $2338-2135$ cal BC \\
\hline SUERC-23243 & Charcoal: Corylus & 379/358 Henge ditch & $3725 \pm 30$ & -25.0 & $2204-2032$ cal BC \\
\hline SUERC-23244 & Charocal: Alnus & 345/334 Henge ditch & $3810 \pm 30$ & -24.5 & $2400-2140 \mathrm{cal} \mathrm{BC}$ \\
\hline SUERC-23248 & Charcoal: Alnus & 362/352 Henge ditch lower fill & $3880 \pm 30$ & -24.3 & $2468-2236 \mathrm{cal} \mathrm{BC}$ \\
\hline SUERC-29176 & Charcoal: Corylus & 609/1034 Henge ditch & $3650 \pm 30$ & -25.1 & 2136-1938 cal BC \\
\hline SUERC-29178 & Charcoal: Quercus & 643/1068 Henge ditch lower fill & $3790 \pm 30$ & -25.5 & $2338-2135 \mathrm{cal} \mathrm{BC}$ \\
\hline SUERC-29179 & Charcoal: Alnus & 645/1068 Henge ditch lower fill & $3780 \pm 30$ & -26.9 & 2296-2059 cal BC \\
\hline SUERC-26112 & Bark : birch & 004 Cist & $3675 \pm 30$ & -27.3 & 2141-1956 cal BC \\
\hline SUERC-29196 & Charcoal: Betula & 801/1115 Cist & $3690 \pm 30$ & -27.0 & 2196-1977 cal BC \\
\hline SUERC-29197 & Charcoal: Corylus & $609 / 1034$ Henge ditch fill adjacent to cist & $3650 \pm 30$ & -25.1 & $2275-2036 \mathrm{cal} \mathrm{BC}$ \\
\hline SUERC-29200 & Wood: cf Salix & SF1020/1110 Cist & $3705 \pm 30$ & -28.8 & 2199-1985 cal BC \\
\hline SUERC-29198 & Seeds : cf Filipendula ulmaria & SF1017/014 Cist flower & $3590 \pm 30$ & -28.7 & 2030-1882 cal BC \\
\hline SUERC-29199 & Flower: Filipendula ulmaria & Cist flower & $3740 \pm 35$ & -30.0 & 2279-2033 cal BC \\
\hline
\end{tabular}


Table 2. Outline phasing of the sequence at the Forteviot ceremonial complex.

\begin{tabular}{|c|c|c|c|}
\hline Phase & $\begin{array}{l}\text { Description: } \\
\text { main } \\
\text { characteristics }\end{array}$ & $\begin{array}{l}\text { Radiocarbon } \\
\text { dating ranges } \\
\text { (95\% confidence } \\
(\text { see Table } 1)\end{array}$ & $\begin{array}{c}\text { Secure } \\
\text { artefact } \\
\text { associations }\end{array}$ \\
\hline $\begin{array}{l}\text { I } \\
\text { Late Neolithic }\end{array}$ & Cremation cemetery & $3090-2638 \mathrm{cal} \mathrm{BC}$ & $\begin{array}{l}\text { Bone pin, undecorated } \\
\text { pottery, ?wooden vessels }\end{array}$ \\
\hline $\begin{array}{l}\text { IIa } \\
\text { Late Neolithic }\end{array}$ & Palisaded enclosure & 2926-2467 cal BC & None \\
\hline $\begin{array}{l}\text { IIb } \\
\text { Late Neolithic }\end{array}$ & Timber circle & $2850-2467 \mathrm{cal} \mathrm{BC}$ & None \\
\hline $\begin{array}{l}\text { III } \\
\text { Late Neolithic/ } \\
\text { Chalcolithic }\end{array}$ & Henge monument & $2468-1938 \mathrm{cal} \mathrm{BC}$ & $\begin{array}{l}\text { Beaker pot sherds in } \\
\text { lower fills }\end{array}$ \\
\hline $\begin{array}{l}\text { IV } \\
\text { EBA }\end{array}$ & Cist burial & 2199-1977 cal BC & $\begin{array}{l}\text { Butterwick type dagger, } \\
\text { bronze knife-dagger, } \\
\text { wooden vessels, } \\
\text { meadowsweet flowers }\end{array}$ \\
\hline
\end{tabular}

to create the enclosure in its final form. On the west side an escarpment forms part of the boundary; it is unclear if this was the case in prehistory or due to more recent erosion.

\section{The timber circle}

Within the palisaded enclosure a near contemporary, but much smaller, timber enclosure was constructed in the Late Neolithic, a timber circle that surrounded the earlier cremation cemetery (Figure 2, centre left). This monument had a diameter of about $45 \mathrm{~m}$. Five postholes of the timber circle were excavated on the north and south sides of the henge which, like the palisaded enclosure postholes, has shown that these held substantial oak posts, around $0.5 \mathrm{~m}$ in diameter. Radiocarbon dates also place it within the time bracket of 2850-2467 cal BC (Figure 4) (Tables $1 \& 2$ ), broadly contemporary with the palisaded enclosure avenue and rather earlier than the henge monument which it surrounds (below). Little direct evidence for use was found and very limited material culture was found in the postholes (cf. Gibson 2005). Nonetheless, it seems likely that a key reason for its construction was to enclose the already existing cremation cemetery, restricting access to these earlier burials.

\section{Construction of the henge}

Within the area defined by the timber circle and again surrounding the earlier cremation cemetery a substantial earthwork henge monument was constructed perhaps a century or two after the construction of the timber circle (Figure 6). Radiocarbon dates from the basal fills suggest that the primary fills within the henge ditch began to accrue rapidly around 2468-2236 cal BC (SUERC-23248, Table 1). The henge was then in use for several centuries (2468-1938 cal BC, Table 2), consistent with a series of other henges in eastern mainland Scotland (Barclay 2005). 


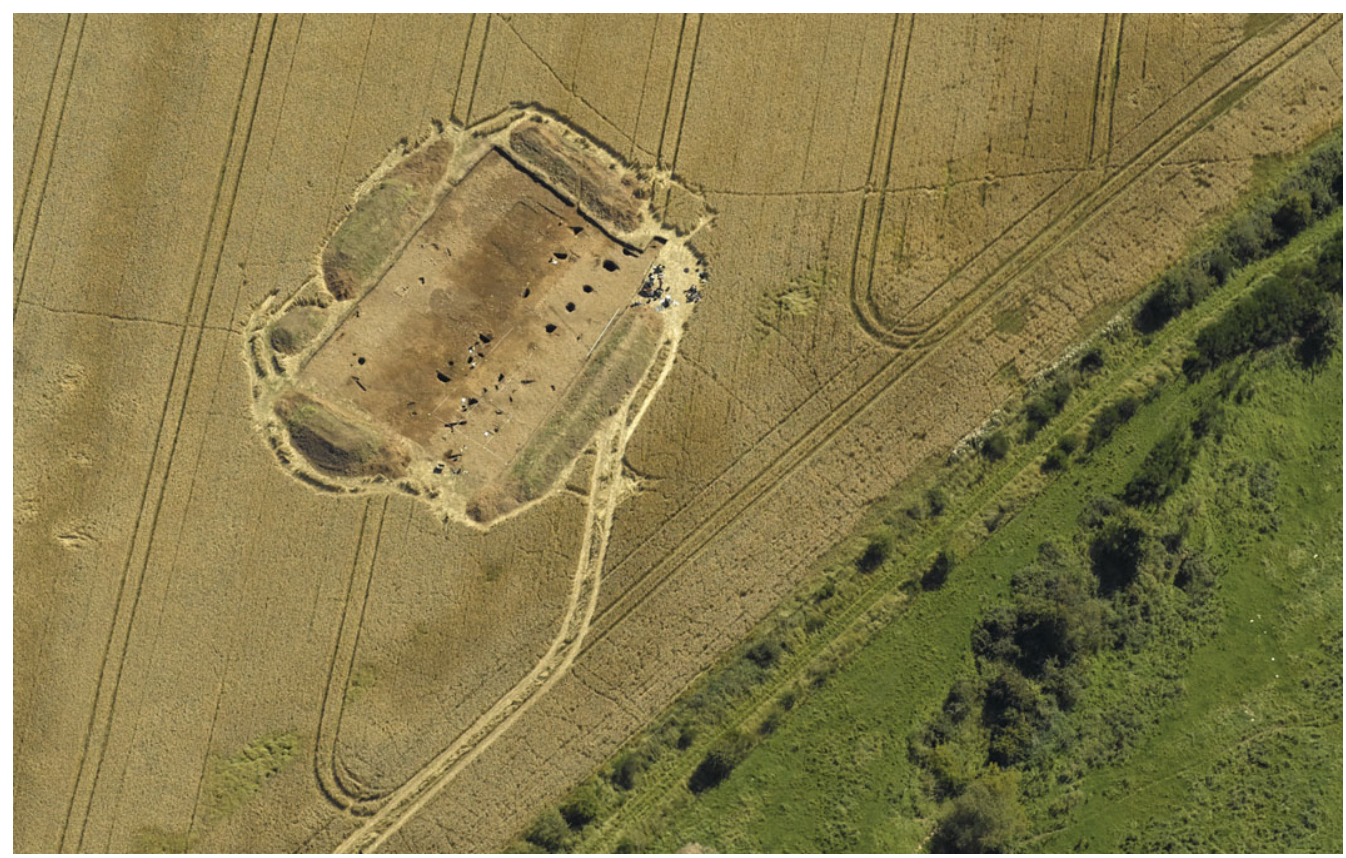

Figure 5. The palisaded enclosure entrance avenue under excavation in 2007 (c) Crown copyright: RCAHMS. Licensor www.rcahms.gov.uk).

The henge defined an internal space some $22 \mathrm{~m}$ across, with a ditch measuring up to $10 \mathrm{~m}$ in width and $1.8-2.8 \mathrm{~m}$ in depth surrounding the central space with a single entrance to the NNW (the same alignment as the palisaded enclosure avenue). Possible traces of an exterior bank were found extending towards and perhaps covering the postholes of the timber circle; the ditch could have provided material for a bank that would have stood $3 \mathrm{~m}$ or higher. Including this putative bank it is possible to envisage a monument with an external diameter of something in the order of $55-65 \mathrm{~m}$, which is a very substantial earthwork monument. Some material, including discrete burnt deposits and a few beaker sherds, were deposited in the henge ditch.

\section{The dagger burial}

By the end of the third millennium BC, a new phase of activity substantially altered the appearance and significance of this locale. In the period 2199-1977 cal BC a cist burial was inserted into the interior of the henge monument (Figures $6 \& 7$ ) (Table 2). The cist was placed at the south-eastern edge of the henge interior and was constructed after the henge ditch had considerably silted up; indeed, the large shallow oval pit in which the cist was constructed cut through the primary cut and fills of the henge ditch. The ditch was not fully silted at this point, however, and the bank was almost certainly still in place. Therefore, the stones that made up the cist and the massive capstone must have been dragged through the entrance of the henge, to take their place in the deepest space of the henge interior. 


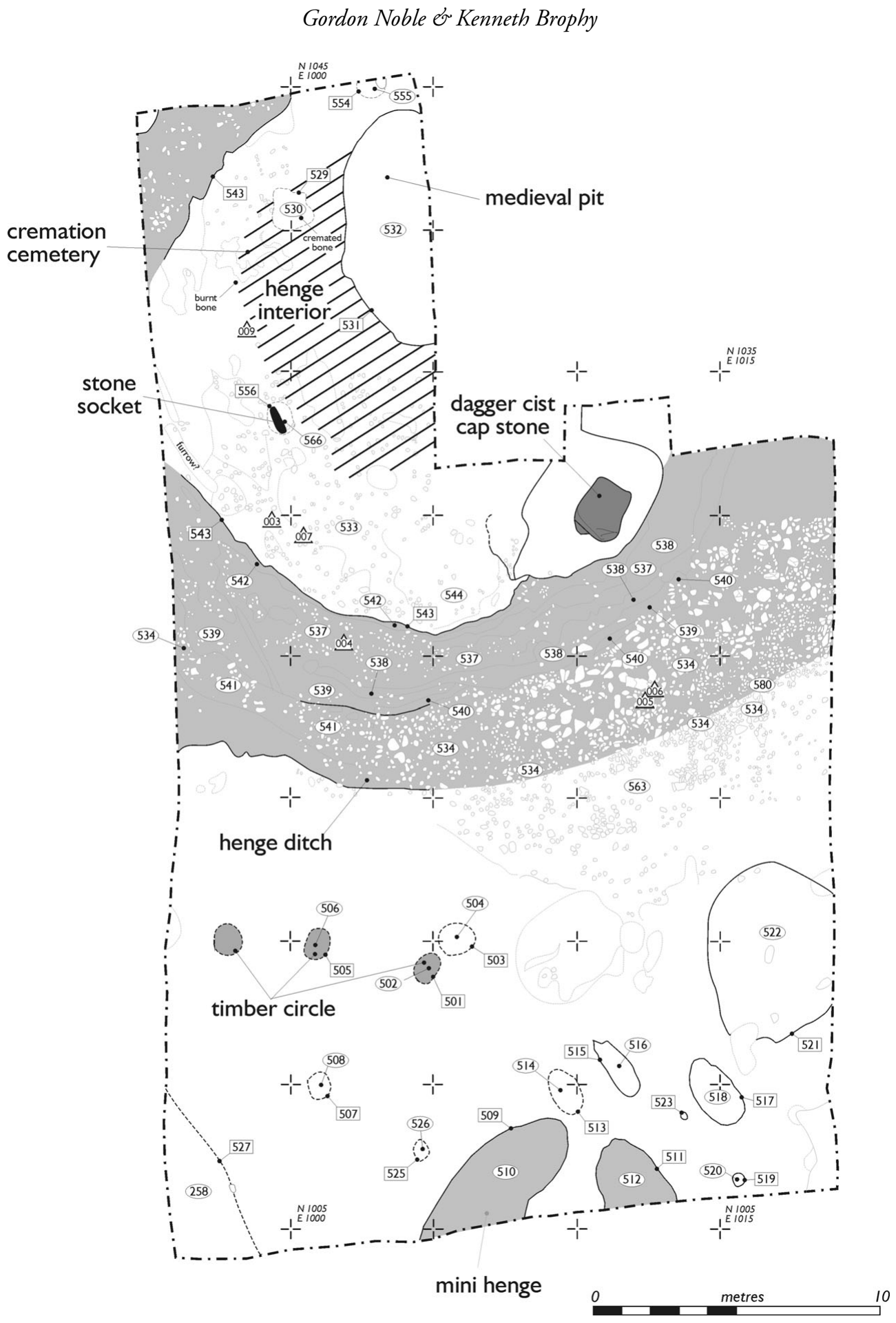

Figure 6. 2009 excavation plan of the henge, showing the position of the exterior timber circle and the interior dagger grave, cremation cemetery and stone socket. 


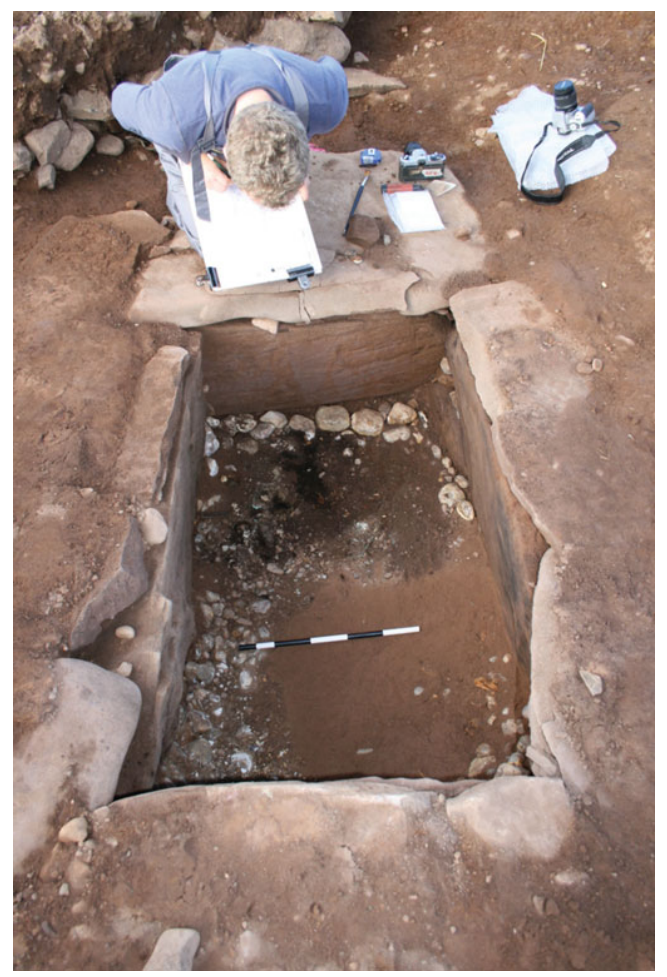

Figure 7. The Forteviot burial cist under excavation: the halo of quartz cobbles can be seen at the end nearest the excavator.
The burial was placed on a natural layer of sand within a large cist constructed from sandstone slabs. Nothing remained of the body upon excavation, although enhanced phosphate levels show that a body originally lay within the grave in a crouched position. This, along with the placement of grave goods and the grave architecture, suggests that the body was laid with the head to the south and a halo of eight large quartz pebbles placed to frame the head and upper body (Figure 7). On the bottom of the cist was found a floor of waterworn pebbles and over this were traces of a mat or bier made of birch bark upon which the body would have lain. A series of grave goods were located around the body. On one side a large bronze dagger with a gold pommel mount, perhaps in a sheepskin sheath, was positioned (Cameron 2010) (Figure 8a). On the other side, a smaller knife or knife-dagger (Figure 8b) was found in association with a remarkable series of partially preserved wooden, animal hide and organic remains and a fire-making kit (Figure 8c), all perhaps contained in a

leather bag. Two of the wooden items seem to represent parts of wooden vessels. Elements of the organic remains have now been identified as flower buds, seeds and other plant material from Filipendula ulmaria (meadowsweet) (Ramsay 2010) (Figure 8d).

The cist was sealed by a huge sandstone slab, weighing in the order of 4-5 tons, which seems to have been quarried specifically for this burial and was probably dragged from a location several kilometres distant. On the quarried face an enigmatic rock art motif was found after the stone was lifted; this was sealed in with the burial, facing the corpse (Figure 9). Over the cist a cairn of quarried basalt slabs and river cobbles was built which probably overlay the henge ditch at least to some extent; traces of this monument were found slumped into the upper fill of the eastern half of the ditch (Brophy \& Noble 2010). After this, a series of burnt deposits were thrown into the ditch from the interior, representing continued use of this monument centuries after its construction.

\section{Discussion}

The sequence of events uncovered at the Forteviot henge shows that this location was a focus for ritual activity for at least a millennium. The first major phase of activity appears to have been the establishment of a cremation cemetery, perhaps associated with stone 

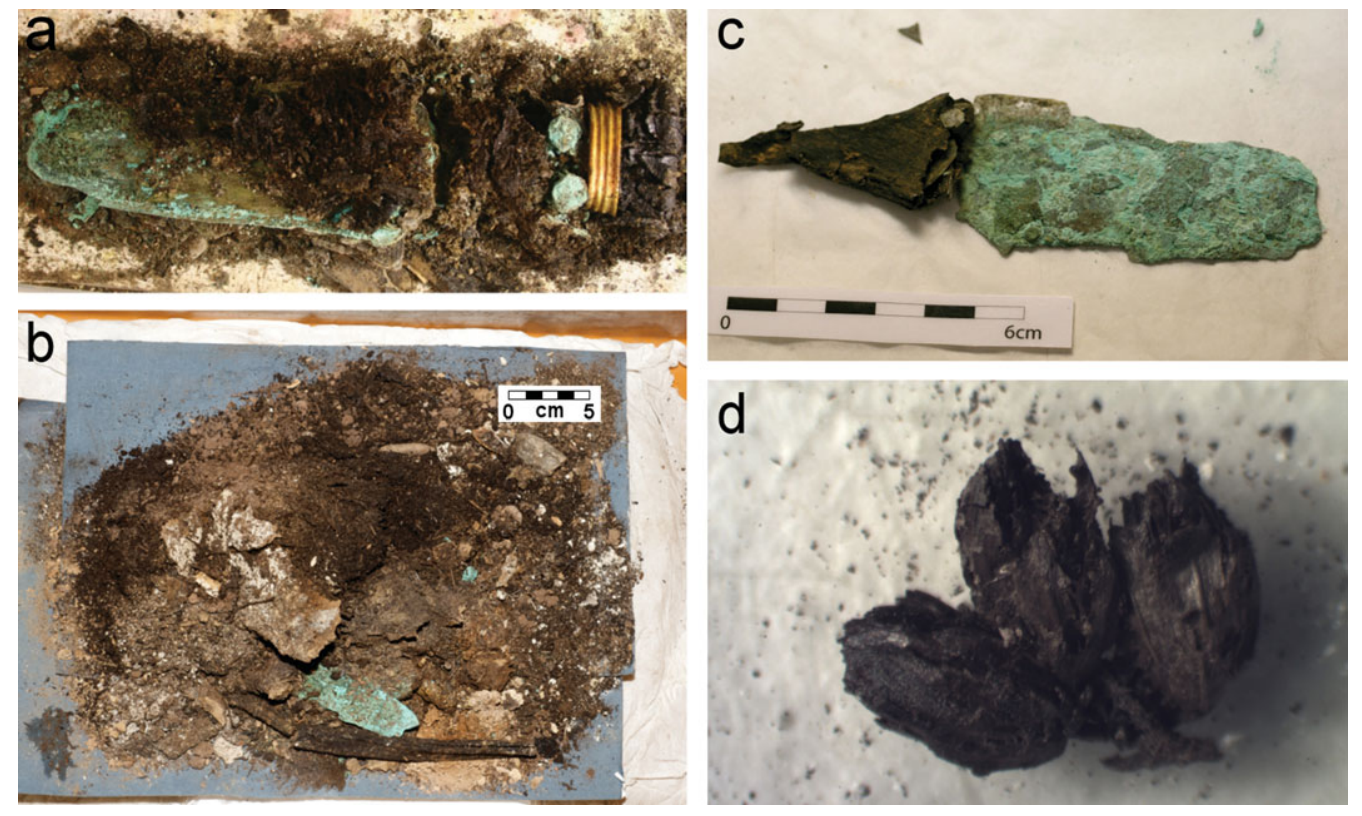

Figure 8. a) The Forteviot bronze dagger under micro-excavation: the remains of the scabbard can be seen on the blade and the gold hilt mount on the right, adjacent to two large rivets; $b$ ) the Forteviot knife-dagger amongst a mass of organic material. Conservation block lift; c) the Forteviot knife-dagger after initial conservation; d) Filipendula ulmaria (meadowsweet) flowerheads from the Forteviot dagger burial (a-d (c) Crown copyright: Historic Scotland).

settings. A close parallel for this may be Cairnpapple in West Lothian, where recent dating suggests this monument complex may have had similar origins (Sheridan et al. 2010). A more distant parallel, but an intriguing one, is Stonehenge where the Aubrey Holes have been recently re-interpreted as the stone sockets for bluestones built in association with a series of cremation burials (Parker Pearson et al. 2009).

The scale of the cemetery at Forteviot remains unclear, in no small part due to later activity at the site. The radiocarbon dates thus far suggest a fairly restricted time-span of use of this cemetery in the centuries after $3000 \mathrm{cal} \mathrm{BC}$. It is tempting to link these burials with a founding family or lineage whose kin had important roles to play in the development of the ceremonial complex that was built in subsequent generations.

The near contemporary construction of two timber enclosures, one big and the other enormous, may well have played a role in enclosing the early third-millennium cal BC cremation cemetery creating different levels of access to the nucleus of this ceremonial complex. The apparently intentional association of timber monuments with this cemetery does not fit well with ethnographically derived models associating the living with timber and the dead with stone - in later Neolithic Britain (cf. Parker Pearson \& Ramilisonina 1998; Parker Pearson et al. 2006).

The construction of both of these timber enclosures would have been remarkable feats of monumental building with, for example, the cutting and dragging of over 200 large oak trees from the surrounding landscape for the construction of the palisade. Excavations at two other palisaded enclosures in Scotland, Meldon Bridge and Dunragit, have provided 

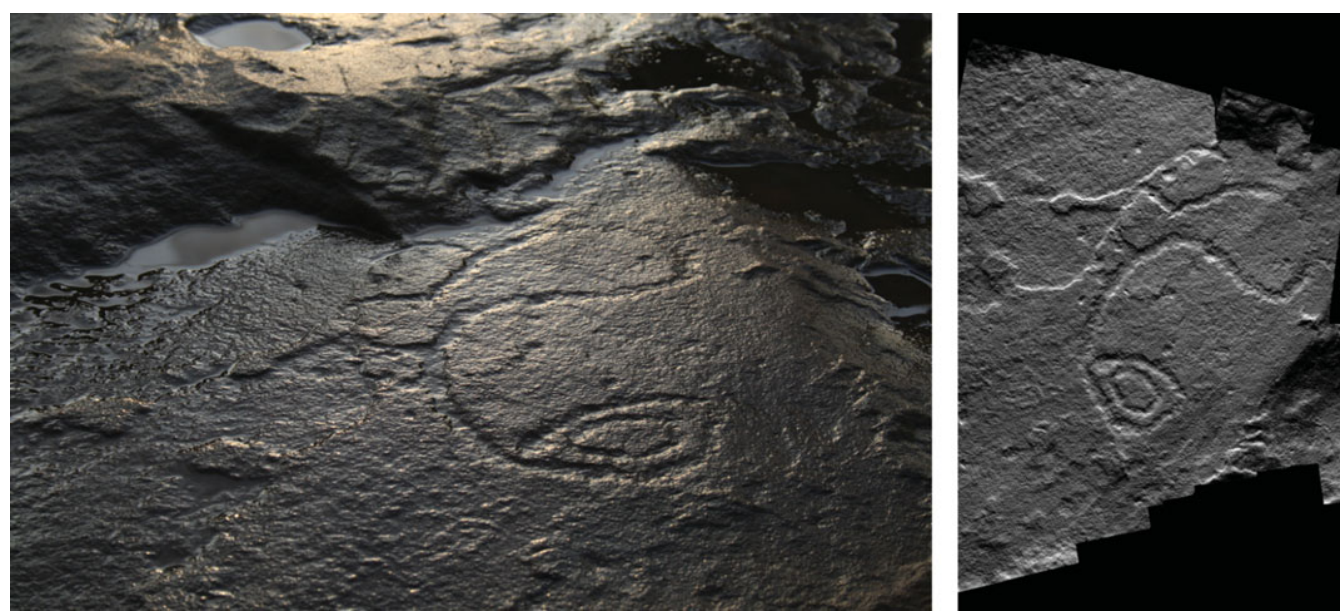

Figure 9. The rock carving on the capstone of the Forteviot dagger burial. Photograph (left), laser scan (right) (Laser scan (C) Crown copyright: Historic Scotland).

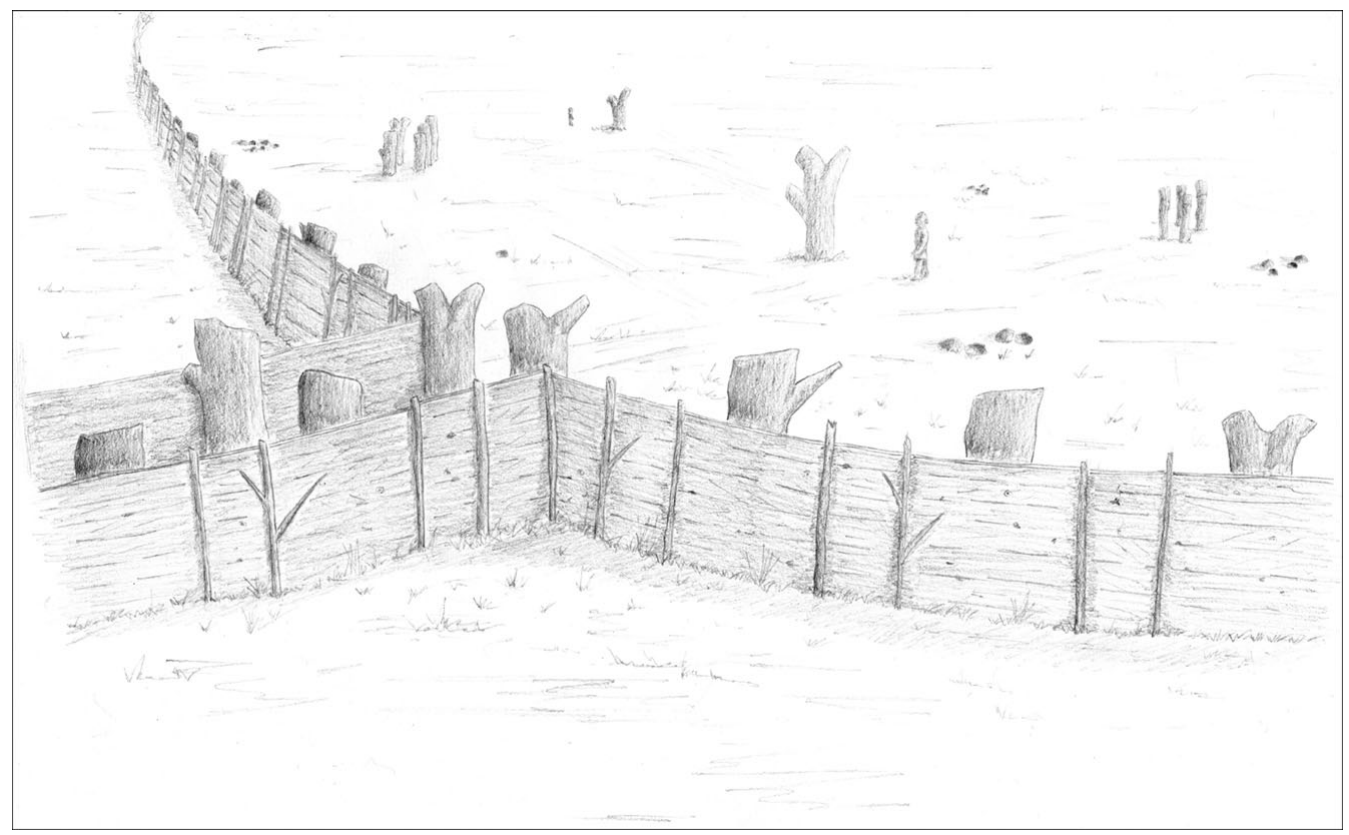

Figure 10. Reconstruction drawing of the Meldon Bridge palisaded enclosure as a continuous boundary (drawing by Dr Kirsty Millican).

evidence for continuous boundaries with smaller interval posts between the main uprights (Speak \& Burgess 1999: 17-19; Thomas 2004) (Figure 10). No such evidence was found at the Forteviot avenue, although due to plough truncation we cannot rule this out, and so the boundary here may have appeared more open and porous with formal entry probably still controlled by the avenue. 
Upon entering the enclosed space of the palisaded enclosure, the much smaller circle of timbers would have been visible further within on the right-hand side. This was one of the larger timber circles in Scotland (Millican 2007), and it enclosed the cremation cemetery which may have appeared as a low mound. The construction of a series of nested spaces that became increasingly exclusionary towards the central focus of these sites seems to have been a common element of Late Neolithic monumentality in Britain (Richards 1993; Barrett 1994; Thomas 2004). If palisaded enclosures were for the large-scale gathering of people as has often been assumed in the past (Gibson 2002), then the timber circle would have restricted access to a much more select group of people, although the boundary would not have entirely prevented spectators from viewing the proceedings inside. However, it could also be argued that rather than defining a restricted space for performance, the act of erecting the timber circle was an act of closure, the boundary closing the cemetery to further use.

The ideas of exclusion and containment could also be said to characterise the construction of the henge. The timber circle postholes suggest that some timbers rotted where they stood while others slumped over, perhaps submerged in the henge bank, with the boundary defined by these posts remade in a more monumental and permanent form. The henge, therefore, may have represented the conclusion of a lengthy entombment of an ancient cemetery.

The placing of the Early Bronze Age cist within the henge monument suggests that in the later third millennium cal $\mathrm{BC}$ the space enclosed by the henge was redefined through a further phase of burial, albeit of a markedly different character to what had gone before. In all, over 40 Bronze Age dagger burials have now been found in Scotland (Sheridan in Baker et al. 2003: 116n), although this is the first found in a prominent location in a Neolithic monument. The unusual context of the burial is also underlined by the rare presence of both a dagger and a knife-dagger, which occurs in only a handful of burials of this type (Baker et al. 2003: appendix).

Massive capstones have been noted as a feature of some dagger grave burials (Henshall 1968), but the nature of the carving at Forteviot again marks this burial as different and special (Figure 9). Vaguely similar markings have been found in a few megalithic mortuary contexts in Scotland (Simpson \& Thawley 1972). However, no close parallels exist for this motif, which may be naturalistic - representing an axe, mace, club or footprint - or abstract. As for the capstone itself, the nearest possible source identified for the sandstone block that made the capstone is located in the Water of May around $1 \mathrm{~km}$ to the south-west of Forteviot. Moving the slab here would have been a monumental task in itself, and judging by the freshness of the carving on the quarried side it is likely that this slab was specifically quarried and moved in preparation for the burial of this individual.

Dagger burials have been described by Sheridan (Baker et al. 2003: 109) as 'high-status early Bronze Age burials'. Where identified, the individuals associated with daggers have been male, and grave goods attest to both a tradition, and materials, drawn from beyond Scotland (Henshall 1964: 172; Baker et al. 2003; Needham 2004: 239; Wilkin 2009: 67). The Forteviot henge, and dagger burial, spans the centuries leading up to $2000 \mathrm{cal} \mathrm{BC}$, from the Late Neolithic through what some have recently characterised as a brief Chalcolithic phase (cf. Sheridan 2008), followed by the Bronze Age proper. During this period, extensive networks developed that involved the flow of objects, materials (and perhaps more rarely people) across widespread areas of the British Isles and possibly the continent, as indicated 
by the stable isotope results of the Amesbury Archer, c. 2400-2200 cal BC (Fitzpatrick 2003).

Beginning in the last centuries of the third millennium cal BC, there was a concentration of dagger burials in eastern central Scotland, Forteviot amongst them (Wilkin 2009). Needham (2004) has suggested that individuals in this area may have acquired status through the control of the flow of tin and copper to metalworking centres located further to the north (Needham 2004), a hint at how the individual buried at Forteviot may have achieved status in society and how the community acquired the materials deposited with the dead. Yet status may have been established in other ways; the association with, and addition to, the already ancient henge was probably also significant (Longden 2003; Noble 2006: ch.8).

However, the dagger grave at Forteviot is a reminder that burial traditions can be as much about coming to terms with loss and discontinuity as communicating the social position of the deceased (Tarlow 1992; Brück 2004: 309). In particular, we have been able to gain a glimpse of the expressions of individual care and attention in the mortuary ritual: the preparation of the birch bark flooring and the abundant plant remains, which includes traces of sphagnum moss and leaf material, is suggestive of the creation of some form of bedding material for the dead and the abundant flower buds, seeds and other plant material of meadowsweet suggests a bunch (or bunches) of flowers were placed with the body (Ramsay 2010). Similar plant remains have been found at other Bronze Age graves in Scotland, most notably the dagger grave at Ashgrove in Fife where the excavator also found bark, moss and other organic materials beneath the body (Henshall 1964). Significantly, meadowsweet pollen was also recovered from Ashgrove, as well as a few other cists found in Scotland (Tipping 1994; Murray et al. 2008), but Forteviot has given us the first direct evidence that flowers were placed with burials in Bronze Age Scotland.

\section{Conclusion}

The excavations at Forteviot have uncovered the evolution of a prehistoric ceremonial complex and burial practice implying a significant regional centre throughout the third millennium cal BC. It has comparisons with developments at Stonehenge and other major Late Neolithic ceremonial complexes. This place, initially used for the placing of cremations in the ground, perhaps in association with a stone circle or setting, became increasingly monumentalised through time, with a nested series of monuments built in relation to what would have became an increasingly ancient (and perhaps mythical) burial site. The treetrunk palisaded enclosure at Forteviot was the largest of these monuments and would have formed an immense enclosed space.

The social structures within which such monumental tasks were carried out seem to have become eclipsed towards the end of the third millennium cal BC, with new networks of power and contact emerging through the increasing importance of metalworking. It was within this social milieu that the dagger grave at Forteviot was placed within the henge monument, its placement in the southern sector of the henge perhaps a hint that the earlier cremation cemetery in the western part of the henge was still remembered in some way. It 


\section{Gordon Noble \& Kenneth Brophy}

may even be that the individual in the dagger burial was being connected in some way to the lineage represented by the earlier burials.

\section{Acknowledgements}

The SERF project is funded by Historic Scotland, the University of Glasgow and the University of Aberdeen. The initial two years of the project were also funded by a British Academy grant (LRG: 45610). We would like to thank our SERF co-director, Stephen Driscoll, for his continuing support and encouragement, and Tessa Poller for her assistance and patience. Thanks also to Alison Sheridan for commenting on an earlier draft of this paper, which focused our minds. Our discussion of the dagger burial grave goods drew largely on the work of a range of colleagues, including the conservator Pieta Greaves, who have been, and still are, working on the contents of the cist, for which we are extremely grateful. Much of the contents of this paper could not have been written without the hard work of a tireless army of students and volunteers who have worked with us at Forteviot since 2006 - our thanks also go out to them.

\section{References}

Aitchison, N.B. 2006. Forteviot: a Pictish and Scottish royal centre. Stroud: Tempus.

AlCoCK, L. \& E.A. AlCOCK. 1992. Reconnaissance excavations on early historic fortifications and other royal sites in Scotland, 1974-84/5: A, Excavations and other fieldwork at Forteviot, Perthshire, 1981; $\mathrm{B}$, Excavations at Urquhart Castle, Inverness-shire, 1983; C, Excavations at Dunnottar, Kincardineshire, 1984. Proceedings of the Society of Antiquaries of Scotland 122: 215-87.

Arabaolaza, I. 2010. SERF'09 Forteviot, Perthshire: cremation analysis report. Report prepared for Glasgow University Archaeological Research Division (GUARD), Glasgow.

BaKer, L., A. Sheridan \& T. Cowie. 2003. An Early Bronze Age dagger grave from Rameldry Farm, near Kingskettle, Fife. Proceedings of the Society of Antiquaries of Scotland 133: 85-123.

BARCLAY, G.J. 2005. The henge and hengiform in Scotland, in V. Cummings \& A. Pannett. (ed.) Set in stone: new approaches to Neolithic monuments in Scotland: 81-94. Oxford: Oxbow.

BARRETT, J.C. 1994. Fragments from antiquity: an archaeology of social life in Britain, 2900-1200 BC. Oxford: Blackwell.

Brophy, K. \& G. Noble. 2010. Forteviot, Perthshire, 2009: excavations of a henge and cist burial. Interim Report and Data Structure Report prepared for the Strathearn Environs and Royal Forteviot (SERF) project, University of Glasgow.

BRƯCK, J. 2004. Material metaphors: the relational construction of identity in Early Bronze Age burials in Ireland and Britain. Journal of Social Archaeology 4(3): 30-33.

CAMERon, E. 2010. Forteviot: SEM analysis of organic remains associated with the Bronze Age knife and dagger. Unpublished report prepared for SERF and Historic Scotland.
Driscoll, S.T., K. Brophy \& G. Noble. 2010. The Strathearn Environs and Royal Forteviot project (SERF). Antiquity 84(323). Available at: http://antiquity.ac.uk/projgall/driscoll323/ (accessed 20 January 2010).

FitZPATRICK, A.P. 2003. The Amesbury archer. Current Archaeology 184: 146-52.

GIBSON, A.M. 2002. The later Neolithic palisaded sites of Britain, in A.M. Gibson (ed.) Behind wooden walls: Neolithic palisaded enclosures in Europe (British Archaeological Reports international series 1013): 5-23. Oxford: Archaeopress.

- 2005. Stonehenge and timber circles. Stroud: Tempus.

Henshall, A.S. 1964. A dagger grave and other cist burials at Ashgrove, Methilhill, Fife. Proceedings of the Society of Antiquaries of Scotland 97: 166-79.

- 1968. Scottish dagger graves, in J.M. Coles \& D.D.A. Simpson (ed.) Studies in ancient Europe: essays presented to Stuart Piggott: 173-95. Leicester: University Press.

LONGDEN, G. 2003. Iconoclasm, belief and memory in medieval Wales, in H. Williams (ed.) Archaeologies of remembrance: death and memory in past societies. 171-92. London \& New York: Kluwer Academic/ Plenum.

Millican, K. 2007. Turning in circles: a new assessment of the Neolithic timber circles of Scotland. Proceedings of the Society of Antiquaries of Scotland 137: 5-34.

Murray, H.K., I.A.G. Shepherd, C. Lamb, N.W. Kerr, A.L. Davies, R. Tipping, A. MukherjeE, M. JAY \& M.P. RICHARDS. 2008. Excavation of a beaker cist burial with meadowsweet at Home Farm, Udny Green, Aberdeenshire. Proceedings of the Society of Antiquaries of Scotland 137: 37-58. 
NeEDHAm, S. 2004. Migdale-Marnoch: sunburst of Scottish metallurgy, in I.A.G. Shepherd \& G.J. Barclay (ed.) Scotland in ancient Europe: the Neolithic and Early Bronze Age of Scotland in their European context: 217-46. Edinburgh: Society of Antiquaries of Scotland.

Noble, G. 2006. Neolithic Scotland: timber, stone, earth and fire. Edinburgh: University Press.

Noble, G. \& K. BRophy. 2008. Excavations at Forteviot palisaded enclosure, 2007. Interim Report and Data Structure Report prepared for the Strathearn Environs and Royal Forteviot (SERF) project, University of Glasgow.

- 2009. Forteviot, Perthshire, 2008: excavations of a henge monument and timber circle. Interim Report and Data Structure Report prepared for the Strathearn Environs and Royal Forteviot (SERF) project, University of Glasgow.

- 2011. Big enclosures: the later Neolithic palisaded enclosures of Scotland in their north-western European context. European Journal of Archaeology 14(1).

Parker Pearson, M., J. Pollard, C. Richards, J. Thomas, C. Tilley, K. Welham \& U. Arabella. 2006. Materializing Stonehenge: the Stonehenge Riverside project and new discoveries. Journal of Material Culture 11: 227-61.

Parker Pearson, M., A. Chamberlain, M. Jay, J. Pollard, C. Richards, J. Thomas, C. Tilley \& K. Welham. 2009. Who was buried at Stonehenge? Antiquity 83: 23-39.

Parker Pearson, M. \& Ramilisonina. 1998. Stonehenge for the ancestors: the stones pass on the message. Antiquity 72: 308-326.

RAMSAY, S. 2010. Forteviot '09 cist samples: preliminary findings. Report prepared for Glasgow University Archaeological Research Division (GUARD), University of Glasgow.

RICHARDS, C. 1993. Monumental choreography: architecture and spatial representation in Late Neolithic Orkney, in C. Tilley (ed.) Interpretative Archaeology: 143-80. Providence (RI): Berg.
ST JOSEPH, J.K.S. 1976. Air reconnaissance: recent results, 40. Antiquity 50: 55-57.

SHERIDAN, A. 2008. Towards a fuller, more nuanced narrative of Chalcolithic and Early Bronze Age Britain 2500-1500 BC. Bronze Age Review 1: 57-78. Available at: http://www.britishmuseum. org/pdf/BAR1_2008_6_Sheridan_c.pdf (accessed 20 January 2010).

Sheridan, A., R. Bradley, R. Schulting. 2010. Radiocarbon dates arranged through the National Museums of Scotland Archaeology Department during 2008/9. Discovery and Excavation in Scotland 10: 212-14.

Simpson, D.D.A. \& J.E. ThaWLEy. 1972. Single grave art in Britain. Scottish Archaeological Forum 4: 81-104.

Speak, S. \& C. Burgess. 1999. Meldon Bridge: a centre of the third millennium BC in Peebleshire. Proceedings of the Society of Antiquaries of Scotland 129: 1-118.

TARLOW, S. 1992. Each slow dusk a drawing down of blinds. Archaeological Review from Cambridge 11(1): 125-40.

Thomas, J. 2004. The later Neolithic architectural repertoire: the case of the Dunragit complex, in R. Cleal \& J. Pollard (ed.) Monuments and material culture: papers in honour of an Avebury archaeologist: Isobel Smith: 98-108. Salisbury: Hobnob Press.

TIPPING, R. 1994. Ritual floral tributes in the Scottish Bronze Age: palynological evidence. Journal of Archaeological Science 21: 133-9.

WILKIN, N.C.A. 2009. Regional narratives of the Early Bronze Age: a contextual and evidence led approach to the funerary practices of east-central Scotland. Unpublished M.Phil. dissertation, University of Birmingham. 